ISSN : 2580-3220, E-ISSN : 2580-4588

J. Mandiri., Vol. 5, No. 1, Juni 2021 (1 - 11)

(C)2017 Lembaga Kajian Demokrasi

dan Pemberdayaan Masyarakat (LKD-PM)

DOI: https://doi.org/10.33753/mandiri.v5i1.161

\section{Jurnal \\ MANDIRI}

\title{
Quality of Service and Brand Trust Against Decisions Using Indihome in Ciputat Area of South Tangerang
}

\author{
Senen \\ Economic Faculty, Pamulang University \\ dosen01889@unpam.ac.id \\ Siswi Wulandari \\ Economic Education Faculty, Indraprasta PGRI University \\ siswiwulandari89@gmail.com
}

\begin{abstract}
The purpose of this study is to know the influence between sales promotion to purchase decisions, to know the influence between the quality of service to purchasing decisions, to know the influence between brand trusts on purchasing decisions. The analysis method used is multiple linear regression using SPSS 25 analysis tool. The object of the research in this study was indihome customers of Ciputat region as many as 100 people with random sampling techniques (probability sampling). The results of the analysis stated that partially sales promotion affects purchasing decisions, partially the quality of service services affects purchasing decisions and partially brand trusts affect purchasing decisions, simultaneously (sales promotion, service quality and brand trust) affect purchasing decisions. Concluded in this study is sales promotion influences the decision to use Indihome, the quality of service influences the decision to use Indihome, brand trust influences the decision to use Indihome, simultaneously the promotion of sales of services and brand trust influences the decision to use Indihome.
\end{abstract}

Keywords : Sales Promotion, Quality Of Service, Brand Trust, Purchasing Decisions

\section{INTRODUCTION}

The development of information and communication technology is now one of the causes of rapid social, economic and cultural changes. One example of the development of information and communication technology at this time is the Internet. The Internet has created a new economic world that has an impact on several aspects of life, not least the development of the business and marketing world. The wide reach of the internet has been widely utilized by people as a medium of marketing and business. This makes business practices through the internet have many advantages for individuals, companies or consumers. Seeing the number of internet users to date that continues to grow rapidly, the internet can be a potential market for business people to enter. Of course, this makes online sales practices that have many advantages for both companies and consumers are widely done. 
Online sales are more than just buying and selling products online. Online sales cover the entire process of marketing, sales, delivery, service, and payment of consumers. In addition to the reasons for business development, the use of internet resources is due to the potential number of internet users around the world which from year to year has increased. Indonesia is among the top 10 Asian countries with the most internet users. Increasing internet penetration in Indonesia has led to a shift in marketing technology.

Internet users are constantly growing into a new market that is quite potential for the company. Internet is a service product that is very easy to operate and can be used by all circles and can be used all the time. That advantage is one of the driving factors in the development of the internet around the world. Internet use has become a lifestyle for some people in the world, as is the case in Indonesia. On one of the websites, explained that internet users in 2017 increased by 112 million people compared to the previous year, while internet access via smartphones reached 51.7 million people.

The increasing need for internet creates competition for internet providers, one of the internet providers that is growing today is Indihome, Indonesia Digital Home or indiHOME is one of the service products of PT. Telecommunication Indonesia in the form of communication and data service packages such as landline (voice), internet (Internet on Fiber or High Speed Internet), and interactive television services (Usee TV Cable, IP TV) because of this offer Telkom labeled IndiHOME as three services in one package (3-in-1) because in addition to the internet, customers also get pay TV shows and telephone lines.

Competition between companies is determined by the number of customers who use the products offered. A purchase decision is a series of processes that start with the consumer getting to know the problem, finding information about a particular product or brand and evaluating the product or brand how well each alternative can solve the problem, which then a series of process- es leads to a purchase decision (Tjiptono, 2016). Many factors influence purchasing decisions, one of which is sales promotion that is, sales promotion is defined as something promotional activities other than advertising, personal selling and publicity that can encourage purchases by consumers and that can increase the effectiveness of dealers by holding exhibitions, displays, exhibitions, demonstrations or demonstrations and various other sales activities. euntungan of sales promotion is a sales promotion can attract the attention of consumers, offer a strong insetif to buy, and can be used to dramatize product offerings. While the disadvantages of sales promotions are that the costs incurred are greater than shortlived advertising and sales promotions. A variety of short-term incentives to encourage the desire to try or buy a product or service, such as giving coupons or other gifts. The sales promotion media is in the form of contests, games, prizes, exhibitions, and coupons.

Another factor is the quality of service services, According to (Tjiptono, 2016), The concept of quality is considered as a measure of perfection of a product or service consisting of design quality and conformance quality. Design quality is a specific function of a product or service, quality conformity is a measure of how much conformity level between a product or service and the requirements or specifications of quality set before.

Another factor is brand trust, which is the desire of customers to rely on a brand with the risks faced because expectations of the brand will lead to positive results. If a brand is able to meet consumer expectations or even exceed consumer expectations and provide quality assurance at every opportunity of its use and the brand as part of itself (Andriana \& Dr. Drs. Ngatno, 2020). According to (Pramezwary et al., 2021) brand trust is a consumer trusting a product with all the risks because there are high expectations or expectations of the brand will give a positive result to consumers so that it will lead to loyalty and trust to a brand. Indihome is an internet service provider that is able to rank top in the Top Brand Award, 
here is the Top Brand period 2016 - 2020. In the table 1 showing top brand award 2016-2020 is presented in the following section: opinions (Sugiyono, 2016) "The viable sample size in the study was between 30 to $500 "$.

Table 1. Top Brand Award 2016 - 2020

\begin{tabular}{clccccc}
\hline No & \multicolumn{1}{c}{ Provider } & 2016 & 2017 & 2018 & 2019 & 2020 \\
\hline 1. & Indihome & $48,1 \%$ & $50,3 \%$ & $42,1 \%$ & $39,8 \%$ & $36,7 \%$ \\
2. & First Media & $18,6 \%$ & $17,3 \%$ & $22,4 \%$ & $29,9 \%$ & $23,1 \%$ \\
3. & Telkomnet Instan & $4,7 \%$ & - & - & - & - \\
4. & Bizznet.net & - & $2,1 \%$ & $6,4 \%$ & $8,3 \%$ & $8,2 \%$ \\
5. & Indosat M2 & - & - & - & $8,9 \%$ & $4,5 \%$ \\
\hline
\end{tabular}

Sumber: https://www.topbrand-award.com, 2021

Based on the data above, indihome is the topranked company with the top brands from year to year, but from year to year the increasing number of competitors is threatening, so there needs to be a proper strategy in convincing customers.

Given the importance of the problem, the authors conducted this study in order to provide benefits for the company in improving the decision to use services to customers so that the company's goals can be achieved. Based on the background description above, then the research was submitted with the title "Influence of Sales Promotion, Quality of Services And Brand Trust On Decisions Using Indihome In Ciputat Area Of South Tangerang".

\section{METHOD}

The research method used is quantitative method. According to (Sugiyono, 2016), "Quantitative method can be interpreted as a research method based on the philosophy of positivism, used to research on a particular population or sample, data collection using research instruments, quantitative/statistical data analysis, with the aim to test established hypotheses".

"Sampling technique is a sampling technique, to determine the sample to be used in the research" (Sugiyono, 2016), in this study the authors used a simple method of random sampling, where all the data can be sampled. In this study, we used a sample of 100 respondents, namely Indihome customers in ciputat area.

Determination of samples based on

\section{RESULTS}

Promotional activities included in this sales promotion e.g. coupon giving, sale, contest, exhibition and others. According to (Ramadani, 2019) Promotion is all efforts of business entities to influence consumers with the aim to consume products and services they sell.

Every company that conducts promotional activities is certainly the main goal is to make a profit according to the (Tjiptono, 2016), in general, promotional activities should be based on the following objectives:

Inform includes Promotional activities that aim to try to inform consumers of a particular brand or product whether it is a new product or brand or a product and brand that has been long but not widely heard by consumers.

Persuade includes Promotional activities that are persuasive and encourage consumers to make purchases of the products offered. The company prioritizes the creation of a positive impression to consumers so that promotions can affect buyer behavior for a long time.

Reminding includes reminding promotional activity is done to maintain the brand of the product in the hearts of the public, and to retain buyers who will make purchases continuously.

According to (Prasetio \& Rismawati, 2018) Sales promotion consists of a collection of incentive tools, mostly short-term, designed to stimulate faster or larger purchases of certain products or services by consumers or trades. Sales promotion is a short-term incentive to drive sales of products or services. Sales promotions are any 
form of long-term offers or incentives intended for buyers, retailers or wholesalers and are designed to obtain a specific and immediate response (Fakhri, 2020).

According to (Tjiptono, 2016), The concept of quality is considered as a measure of perfection of a product or service consisting of design quality and conformance quality. Design quality is a specific function of a product or service, quality conformity is a measure of how much the level of conformity between a product or service and the requirements or specifications of quality set before.

According to (Soenawan \& Malonda, 2015) Service is any action or performance that one party can offer to another party, which is fundamentally intangible and does not result in ownership of something, basically, everyone who uses the service tends to expect a good service in a high quality sense. The level of service quality (service) is a crucial aspect in the total service offering. Quality is one of the important factors used by consumers to evaluate the services of an organization.

The quality of service has a direct relationship with purchasing decisions and the ability to compete with the level of profit obtained by the company. Therefore the quality of service needs to get great attention from the manager (Panjaitan \& Suryoko, 2016). The quality of service is defined as economic activity that produces time, place, form or psychological usefulness. The quality of service can be realized through the fulfillment of consumer needs and desires as well as the accuracy of delivery to keep pace with consumer expectations. One factor in customer satisfaction in addition to product quality, price, and emotional factor is the quality of service. Consumers feel satisfied and loyal, if they get a good quality of service or as expected (Boediono et al., 2018).

According to (Pratiwi-, 2020), Brand trust is a perception of reliability from a consumer point of view based on experience or more on the sequences of transactions or interactions characterized by full expectations of product performance and satisfaction.
Trust is considered as an encouragement in various transactions between sellers and buyers so that customer satisfaction can occur as desired. After consumers consume the product and use it in real terms it will generate consumer confidence and cause complacency (Sari \& Sanjaya, 2020). Thus trust is defined as a willingness to rely on relationships with partners based on belief. Trust is the consumer's desire to rely on the company and the willingness to rely on relationships with its partners based on the beliefs of.

Brand trust is the willingness of consumers because of the expectations promised by the brand in providing positive results for consumers, the feeling of safety obtained by consumers in their interactions with brands based on the perception that the brand is reliable and meets the interests and safety of consumers (Irwinsyah \& Nurlatifah, 2020). Brand trust is a perception of reliability from a consumer's point of view based on ignition, or more on the sequences of transactions or interactions characterized by the fulfillment of expectations for product performance and satisfaction (Mamahit et al., 2015). Customer trust in a brand is defined as a customer's desire to rely on a brand at risk because expectations for that brand will lead to positive results (Adiwidjaja, 2017).

Consumer decision in purchasing a product is an action that is commonly carried out by every individual consumer when making a decision to buy. Purchasing decisions are decisions taken by consumers to purchase a product that begins with the introduction of needs, obtaining information, assessing and comparing several alternative purchases that exist (RACHMAN, 2017).

According to (Ruhamak \& Rahmadi, 2019), Consumer decision in purchasing a product is an action that is commonly carried out by every individual consumer when making a decision to buy. The decision to buy or not to buy is part of an element inherent in an individual consumer's self called behavior where it refers to real physical action. Purchasing decisions are the decisionmaking process until the consumer actually buys the product. Purchasing decisions are the actions 
of consumers to be willing to buy or not to a product (Njoto \& Sienatra, 2018).

A consumer in purchasing a product will look at a product from various points of view, this is called the stages of the purchasing decision process. According to (Kotler, Philip dan Amstrong, 2016) Consumer purchasing decision process consists of five stages conducted by a consumer before reaching the decision stage of purchase and the next post-purchase stage. In the figure 1 showing stages of the purchasing decision process is presented in the following section:

Problem
Recognition $\rightarrow \begin{gathered}\text { Information } \\ \text { Research }\end{gathered} \rightarrow \begin{aligned} & \text { Evaluation of } \\ & \text { Alternatives }\end{aligned} \rightarrow \begin{gathered}\text { Purchase } \\ \text { Decision }\end{gathered} \rightarrow \begin{gathered}\text { Postpurchase } \\ \text { Decision }\end{gathered}$

Figure 1. Stages of The Purchasing Decision Process

The explanation of the five stages is as Problem Recognition, At this stage consumers know there are problems or needs that must be resolved or met. Second stages, Information Research, At this stage consumers are looking for as much information as possible on alternative options for goods or services needed and desired. Third stages, Evaluation of Alternatives, consumers will evaluate the benefits of the product or service to be purchased from various alternatives available. Fourth stages, Purchase Decision, at this stage the council has set options on one alternative and made a purchase. Fifth, Postpurchase Decision, At the post-purchase stage, consumers will experience a level of satisfaction and dissatisfaction.

In the table 1 showing test results of validity of sales promotion, quality of service, brand trust and purchase decision is presented in the following section:
Table 1. Test Results of Validity of Sales Promotion, Quality of Service, Brand Trust and Purchase Decision

\begin{tabular}{|c|c|c|c|}
\hline Item Pertanyaan & $\begin{array}{c}\text { Corrected } \\
\text { Item-Total } \\
\text { Correlation } \\
\left(\mathrm{r}_{\text {hitung }}\right)\end{array}$ & $r_{\text {tabel }}$ & Keterangan \\
\hline \multicolumn{4}{|c|}{ Promosi Penjualan (X1) } \\
\hline PP1 & 0,505 & 0,196 & Valid \\
\hline PP2 & 0,537 & 0,196 & Valid \\
\hline PP3 & 0,542 & 0,196 & Valid \\
\hline PP4 & 0,741 & 0,196 & Valid \\
\hline PP5 & 0,895 & 0,196 & Valid \\
\hline PP6 & 0,779 & 0,196 & Valid \\
\hline PP7 & 0,886 & 0,196 & Valid \\
\hline \multicolumn{4}{|c|}{ Kualitas Layanan Jasa (X2) } \\
\hline KP1 & 0,731 & 0,196 & Valid \\
\hline KP2 & 0,757 & 0,196 & Valid \\
\hline KP3 & 0,715 & 0,196 & Valid \\
\hline KP4 & 0,644 & 0,196 & Valid \\
\hline KP5 & 0,700 & 0,196 & Valid \\
\hline KP6 & 0,684 & 0,196 & Valid \\
\hline KP7 & 0,620 & 0,196 & Valid \\
\hline KP8 & 0,691 & 0,196 & Valid \\
\hline KP9 & 0,731 & 0,196 & Valid \\
\hline KP10 & 0,623 & 0,196 & Valid \\
\hline \multicolumn{4}{|l|}{ Brand Trust (X3) } \\
\hline BT1 & 0,726 & 0,196 & Valid \\
\hline BT2 & 0,757 & 0,196 & Valid \\
\hline BT3 & 0,801 & 0,196 & Valid \\
\hline BT4 & 0,799 & 0,196 & Valid \\
\hline BT5 & 0,615 & 0,196 & Valid \\
\hline BT6 & 0,683 & 0,196 & Valid \\
\hline
\end{tabular}

Sumber: https://www.topbrand-award.com, 2021

Based on the results of the validity test that all variables are declared valid because it has a rcount value $>$ rtable then it can be concluded that the statement in this study is worth using as a study.

In the table 2 showing test results sales promotion reliability, service quality, brand trust and purchasing decisions is presented in the following section: 
Table 2. Test Results Sales Promotion Reliability, Service Quality, Brand Trust and Purchasing Decisions

\begin{tabular}{lccc}
\hline Question Item. & $\begin{array}{c}\text { Cronbach's } \\
\text { Alpha }\end{array}$ & $\begin{array}{c}\text { N of } \\
\text { Item }\end{array}$ & Description \\
\hline $\begin{array}{l}\text { Sales Promotion } \\
\text { (X1) }\end{array}$ & 0,894 & 7 & Reliable \\
$\begin{array}{l}\text { Service Quality } \\
\text { (X2) }\end{array}$ & 0,916 & 10 & Reliable \\
$\begin{array}{l}\text { Brand Trust } \\
\text { (X3) }\end{array}$ & 0,899 & 6 & Reliable \\
$\begin{array}{l}\text { Purchase } \\
\text { Decision (Y) }\end{array}$ & 0,872 & 10 & Reliable \\
\hline
\end{tabular}

Based on the reliability test that cronbach's alpha value is greater than 0.70 , this proves that all variables are declared reliable.

The classic assumption test in this study consists of normality test, multicolinearity test and heteroskedastisity test, here is the explanation (Ghozali 2018).

In the figure 2 showing data normality test results is presented in the following section:

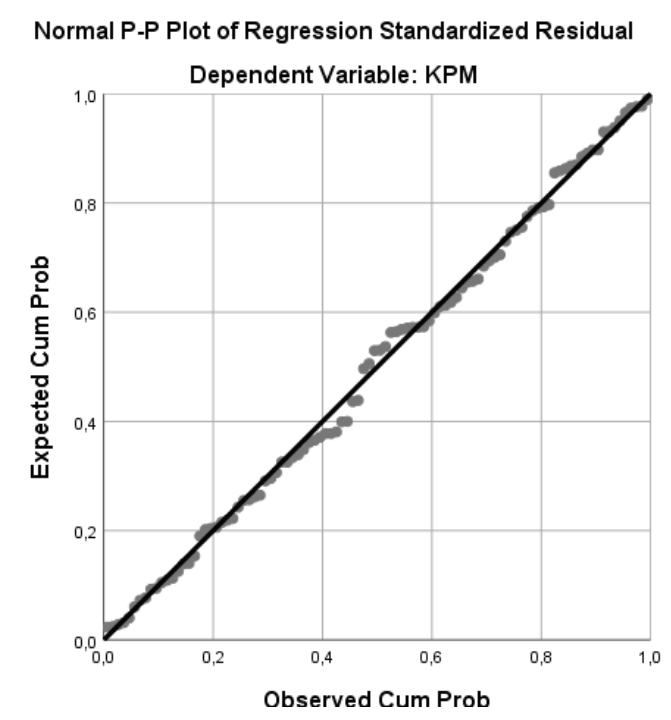

Figure 2.Data Normality Test Results

Based on the data above the points approaching the diagonal line, this proves that the data is normally distributed, it can be concluded that the data deserves to be used as research.

In the table 3 showing the results of multicolinearity tests is presented in the following section:

Table 3. The Results of Multicolinearity

\begin{tabular}{|c|c|c|c|}
\hline \multicolumn{4}{|c|}{ Coefficients $^{\mathrm{a}}$} \\
\hline & \multirow{2}{*}{ Model } & \multicolumn{2}{|c|}{ Collinearity Statistics } \\
\hline & & Tolerance & VIF \\
\hline \multirow[t]{4}{*}{1} & (Constant) & & \\
\hline & $\mathrm{PP}$ & ,419 & 2,386 \\
\hline & KP & 275 & 3,637 \\
\hline & BT & ,309 & 3,232 \\
\hline
\end{tabular}

Based on the results of the multicolinearity test is stated not to occur multicolinearity, because the VIF value is smaller than 10 and the tolerance value is greater than 0.10 , then this research is worth using as a study.

In the figure 3 the results of heteroskedastisitas tests is presented in the following section:

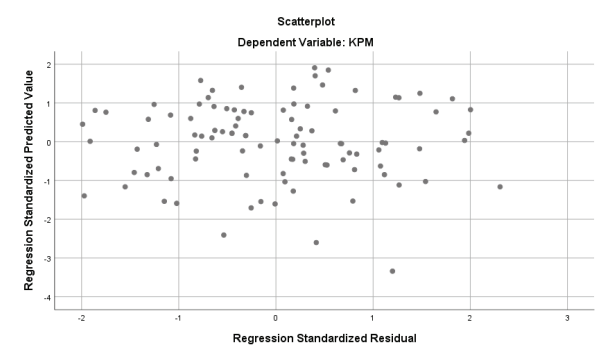

Figure 3.Heterocedastisity Test Results

Based on the results of the heteroskedastisity test, the data does not occur heterokedastisity because the points on the graph scaterplot spread, do not form a pattern, do not collect and are above and below zeros, it is worth research.

In the table 4 showing the results of the correlation coefficient is presented in the following section: 
Table 4. The Results of the Correlation Coefficient

\begin{tabular}{llcccc}
\hline \multicolumn{6}{c}{ Correlations } \\
& & KPM & PP & KP & BT \\
\hline Pearson & KPM & 1,000 &, 800 &, 880 &, 852 \\
Correlation & PP &, 800 & 1,000 &, 744 &, 705 \\
& KP &, 880 &, 744 & 1,000 &, 818 \\
& BT &, 852 &, 705 &, 818 & 1,000 \\
Sig. & KPM & $\cdot$ & 0,000 & 0,000 & 0,000 \\
(1-tailed) & PP & 0,000 &. & 0,000 & 0,000 \\
& KP & 0,000 & 0,000 &. & 0,000 \\
& BT & 0,000 & 0,000 &, 000 &. \\
N & KPM & 100 & 100 & 100 & 100 \\
& PP & 100 & 100 & 100 & 100 \\
& KP & 100 & 100 & 100 & 100 \\
& BT & 100 & 100 & 100 & 100 \\
\hline
\end{tabular}

Based on table 4 in the correlation coefficient it appears that the relationship between the purchase decision and the sales promotion of 0.800 or has a very strong relationship, the relationship of the purchase decision with the quality of service of 0.880 or has a very strong relationship, the relationship between the purchase decision and the brand trust of 0.852 has a very strong relationship, the relationship between the sales promotion and the quality of service as basic as 0.744 has a strong relationship, the relationship between sales promotion and brand trust of 0.705 has a strong relationship, the relationship between the quality of service and brand trust of 0.818 has a very strong relationship.

In the table 5 showing partial test results ( $t$ test) between independent variables (sales promotion, service quality and brand trust) against dependent variables (purchasing decisions) is presented in the following section:

Table 5. Partial Test Results (t Test) between Independent

Variables (Sales Promotion, Service Quality And Brand

Trust) Against Dependent Variables (Purchasing Decisions)

\begin{tabular}{llllll}
\hline \multicolumn{7}{c}{ Coefficients $^{\mathrm{a}}$} \\
\multicolumn{7}{c}{ Unstandardized Standardized } \\
Model & Coefficients Cofficients \\
& B & Std. Error & Beta & t & Sig. \\
\hline 1 (Constant) &, 645 &, 145 & & 4,439 &, 000 \\
PP &, 206 &, 049 &, 255 & 4,428 &, 000 \\
KP &, 361 &, 063 &, 425 & 5,726 &, 000 \\
BT &, 287 & 0,62 &, 324 & 4,629 &, 000 \\
\hline a. Dependent Variable: KPM & & & \\
\hline
\end{tabular}

Based on the results of the test $t$ (partially) it appears that the variable sales promotion has a partial influence on the purchase decision, the quality of service has a partial influence on the purchase decision and the brand trust has a partial influence on the purchase decision.

In the table 6 showing test results of simultaneous testing (test F) between independent variables (sales promotion, service quality and brand trust) against dependent variables (purchasing decisions) is presented in the following section:

Table 6. Simultaneous Test Results (Test F) between Independent Variables (Sales Promotion, Service Quality And Brand Trust) Against Dependent Variables (Purchasing Decisions)

\begin{tabular}{|c|c|c|c|c|c|c|}
\hline \multicolumn{7}{|c|}{ ANOVA $^{\mathrm{a}}$} \\
\hline & Model & $\begin{array}{l}\text { Sum of } \\
\text { Squares }\end{array}$ & $\mathrm{df}$ & $\begin{array}{l}\text { Mean } \\
\text { Square }\end{array}$ & $\mathrm{F}$ & Sig. \\
\hline \multirow[t]{3}{*}{1} & Regression & 23,638 & 33 & 7,879 & 187,957 &, $000^{b}$ \\
\hline & Residual & 4,024 & 96 &, 042 & & \\
\hline & Total & 27,662 & 99 & & & \\
\hline
\end{tabular}

a. Dependent Variable: KPM

b. Predictors: (Constant), BT, PP, KP

Based on table 6, it appears that simultaneously independent variables (sales promotion, service quality and brand trust) have an influence on dependent variables (purchasing decisions), because they have a sig value. 0.000 $<0.05$ and Fcount value (187.957) $>$ Ftable (2.70).

In the table 7 showing test results of multiple linear regression coefficients is presented in the following section:

Table 7. Multiple Linear Regression Coefficient Results

\begin{tabular}{|c|c|c|c|c|}
\hline \multicolumn{5}{|c|}{ Coefficients $^{\mathrm{a}}$} \\
\hline & \multirow{2}{*}{ Model } & \multicolumn{2}{|c|}{$\begin{array}{l}\text { Unstandardized } \\
\text { Coefficients }\end{array}$} & \multirow{2}{*}{$\begin{array}{c}\text { Standardized } \\
\text { Coefficients } \\
\text { Beta }\end{array}$} \\
\hline & & B & $\begin{array}{l}\text { Std. } \\
\text { Error }\end{array}$ & \\
\hline 1 & (Constant) &, 645 &, 145 & \\
\hline & PP & ,206 & 049 &, 255 \\
\hline & KP & ,361 & ,063 & ,255 \\
\hline & BT & 287 & 0,62 &, 255 \\
\hline
\end{tabular}

a. Dependent Variable: KPM 
Based on the results of multiple linear regression coefficients, the following equations are formed:

$$
\mathrm{Y}=0,645+0,206 \mathrm{X} 1+0,361 \mathrm{X} 2+0,287 \mathrm{X3}
$$

In the regression equation above shows a constant value of 0.645 . This states that if the variable sales promotion, service quality and brand trust are considered constant or worth 0 (zero), then the purchase decision will increase by 0.645 or by $64.5 \%$.

The regression coefficient on the sales promsoi variable is 0.206 , this means that if the sales promotion variable increases by one unit then the purchase decision variable will increase by 0.206 or by $20.6 \%$. With a record other variables are considered constants.

The regression coefficient on service quality variable is 0.361 , this means that if the service quality variable increases by one unit then the purchase decision variable will increase by 0.361 or by $36.1 \%$. With a record other variables are considered constants.

The coefficient of regression in brand trust variables is 0.287 , this means that if the brand trust variable increases by one unit then the purchase decision variable will increase by 0.287 or by $28.7 \%$. With other variable records considered constant.

In the table 8 showing test results of the determination coefficient (Adjusted R Square) is presented in the following section:

Table 8. Result Of Determination Coefficient (Ad-

\begin{tabular}{lcccr}
\multicolumn{5}{c}{ justed R Square) } \\
\hline Model & $\mathrm{R}$ & $\begin{array}{c}\mathrm{R} \\
\text { Square }\end{array}$ & $\begin{array}{c}\text { Adjusted R } \\
\text { Square }\end{array}$ & $\begin{array}{l}\text { Std. Error of } \\
\text { the Estimate }\end{array}$ \\
\hline 1 &, $924^{\mathrm{a}}$ &, 855 &, 850 &, 20475
\end{tabular}

a. Predictors: (Contant), BT, PP, KP

b. Dependent Variable: KPM

The determination coefficient aims to find out how much the ability of independent variables (sales promotion, service quality and brand trust) is able to explain dependent variables (purchasing decisions). Based on the table above known adjusted R square value of 0.850 (85\%), This shows that by using the regression model ob- tained where independent variables namely sales promotion, the quality of service and brand trust has an influence on the variable purchase decision of $85 \%$. While the rest $(100 \%-85 \%=15 \%)$ explained by other unknown factors or variables and not included in this regression analysis, such as price, brand image and others.

\section{DISCUSSIONS}

Based on the results of a partially multiple linear regression analysis of sales promotion variables having an influence on purchasing decisions, this is seen in the test results thas a thitung value $(4,248)>$ ttabel $(1.98)$ and sig value. $(0.000)<0.05$. This proves that it has an influence on purchasing decisions. The result of multiple linear regression coefficients also resulted in a value of 0.206 , this proves that the large influence of sales promotion by 0.206 and positive means that the greater the sales promotion, the better the consumer's decision to use Indihome.

The results of the study in accordance with the research conducted by (Prasetio \& Rismawati, 2018) The results of this study show that (1) sales promotions are in a weak indication, especially in the incentive tools offered (2) In general, the purchase decision is quite good (3) There is an influence of sales promotion on the purchase decision. Other research is also in line with that conducted by (Afifi, 2020) based on the results of the analysis of $t$ test significance value from the table Coefficient obtained significance value of 0.000 $<0.05$, so that from the result can be concluded that the variable Sales Promotion (X) affects the variable Purchase Decision (Y).

Based on the results of a partial analysis of linear regression of service quality variables has an influence on purchasing decisions, this is seen in the test results $t$ has a value of thitung $(5,726)$ $>$ ttabel $(1.98)$ and sig value. $(0.000)<0.05$. This proves that the quality of service has an influence on purchasing decisions. The result of multiple linear regression coefficients also resulted in a value of 0.361 , this proves that the large influence of service quality of 0.361 and positive means 
that the greater the quality of service, the better the decision of consumers to use Indihome.

The results of the study in accordance with the research conducted by (Soenawan \& Malonda, 2015) The results showed that product quality, service quality and price had a significant positive influence both partially and simultaneously on the consumer purchase decision of D'Stupid Baker Surabaya. Other research in line conducted by (Lubis, 2017) The analysis of multiple linear regressions $\hat{\mathrm{Y}}=13,731+0.413 \mathrm{X} 1+0.697 \mathrm{X} 2$ means that there is a positive influence between service quality and price on purchasing decisions. The strength of the relationship of the three variables is very strong, i.e. $r=0.834$. From the coefficient of determination can be explained high low employee performance $69.6 \%$, and the remaining $30.4 \%$ explained by other factors that were not discussed in this study. From the results of processing and calculation of questionnaires, the author concluded that the quality of service and price applied by PT Lovely Holidays Tour and Travel Pematangsiantar Branch had a positive and significant effect on purchasing decisions. This is evidenced by simultaneous hypothetical tests, where the results of the fcalculating test $(43,499)>$ ttable $(3.24)$ with a significance of $0.000<$ alpha 0.05 .

Based on the results of a partial analysis of multiple linear regressions of brand trust variables having an influence on purchasing decisions, this is seen in the test results $t$ has a thitung value $(4,629)>$ ttabel $(1.98)$ and a sig value. $(0.000)<0.05$. This proves that brand trusts have an influence on purchasing decisions. The result of multiple linear regression coefficients also resulted in a value of 0.287 , this proves that the greater the influence of brand trust by 0.287 and positive means that the greater the brand trust, the better the consumer's decision to use Indihome.

The results of the study in accordance with the research conducted by (Adiwidjaja, 2017) The results showed that brand image and brand trust have a positive and significant effect on purchasing decisions. Other research in line conducted by (Mamahit et al., 2015) the results showed that brand image, brand trust and product quality simultaneously and partially significantly influenced the purchase decision.

\section{CONCLUSION}

Based on the results of the study showed that, there is an influence of sales promotion on purchasing decisions is 0.206 this is seen from the results of hypothetical tests, so there is an influence of sales promotion on the decision to use Indihome services in ciputat region. There is an influence on the quality of service services on purchasing decisions is 0.361 this is seen from the results of hypothetical tests, so there is an influence on the quality of service services to the decision to use Indihome services in ciputat region. There is an influence of brand trust on purchasing decisions is 0.287 this is seen from the results of hypothesis tests, so there is an influence of brand trust on the decision to use Indihome services in ciputat region. Based on the results of simultaneous analysis of independent variables (sales promotion, service quality and brand trust) has an influence on dependent variables (purchasing decisions), because it has a sig value. $0.000<0.05$ and Fcalculate (187.957) > Ftabel (2.70).

\section{ACKNOWLEDGEMENT}

On this occasion we would like to express our gratitude to the pamulang university that has financed this research and to fellow research lecturers who have been doing well until the completion of this research.

\section{REFERENCES}

Adiwidjaja, A. J. (2017). Pengaruh Brand Image Dan Brand Trust Terhadap Keputusan Pembelian Sepatu Converse. Agora - Online Graduate Humanities Journal, 5(3).

Afifi, G. R. (2020). Pengaruh Promosi Penjualan Terhadap Keputusan Pembelian Produk Narapidana Lembaga Pemasyarakatan Kelas 1 Cirebon (Pas Mart). Jurnal Pendidikan Ekonomi UM Metro, 8(1), 9-17. 
Andriana, N. C., \& Dr. Drs. Ngatno, M. M. (2020). Pengaruh Brand Image Dan Brand Trust Terhadap Keputusan Pembelian Melalui Minat Beli Sebagai Variabel Intervening. Jurnal Administrasi Bisnis.

Boediono, M., Christian, S., \& Immanuel, D. M. (2018). Pengaruh Kualitas Produk dan Kualitas Layanan Terhadap Keputusan Pembelian Konsumen Sealantwax. Jurnal Manajemen Dan Start-Up Bisnis, 3(April), 1-10.

Fakhri, R. (2020). Pengaruh Promosi Penjualan Terhadap Keputusan Pembelian Mebel Pada Cv. Lautan Rezeki Pekanbaru. Eko Dan Bisnis: Riau Economic and Business Review, 11(3), 255-261. https://doi.org/10.36975/ jeb.v11i3.283.

Ghozali, I. (2018). Aplikasi Analisis Multivariate dengan Program IBM SPSS 25. Badan Penerbit Universitas Diponegoro.

Irwinsyah, H., \& Nurlatifah, H. (2020). Analisis Pengaruh Brand Trust, Product Factor, dan Sales Promotion Terhadap Customer Loyalty Melalui Purchase Decision di Matahari Departement Store. Jurnal Al Azhar Indonesia Seri Ilmu Sosial, 1(1), 19. https://doi. org/10.36722/jaiss.v1i1.457.

Kotler, Philip dan Amstrong, G. (2016). Marketing An Introduction. Perason Education.

Lubis, S. A. (2017). PENGARUH KUALITAS PELAYANAN DAN HARGA TERHADAP KEPUTUSAN PEMBELIAN PELANGGAN PADA PT LOVELY HOLIDAYS TOUR AND TRAVEL CABANG PEMATANGSIANTAR. 3(1), 31-39.

Mamahit, P., Soegoto, A. S., \& Tumbuan, W. A. (2015). Pengaruh Brand Image, Brand Trust, dan Quality Terhadap Keputusan Pembelian Mobil Toyota All New Yaris. Jurnal Berkala Ilmiah Efisiensi, 15(05), 777-787. https:// ejournal.unsrat.ac.id/index.php/jbie/article/ viewFile/10473/10059.

Njoto, D. P., \& Sienatra, K. B. (2018). Pengaruh Promosi Terhadap Keputusan Pembelian Konsumen Wenak Tok. Pengaruh Harga Diskon Dan Persepsi Produk Terhadap Nilai Be- lanja Serta Perilaku Pembelian Konsumen, 7(9), 27-44.

Panjaitan, V. M., \& Suryoko, S. (2016). Pengaruh Harga Dan Kualitas Pelayanan Terhadap Keputusan Pembelian (Studi Kasus Pada Taman Rekreasi Wonderia Semarang). Jurnal Ilmu Administrasi Bisnis, 1(1), 1-10.

Pramezwary, A., Juliana, J., Winata, J., Tanesha, R., \& Armando, T. (2021). Brand Trust dan Promosi Penjualan Terhadap Keputusan Pembelian Produk Di Masa Covid-19. Jurnal Perspektif, 19(1), 24-31. https://doi. org/10.31294/jp.v19i1.9376.

Prasetio, B., \& Rismawati, Y. (2018). Pengaruh Promosi Penjualan Terhadap Keputusan Pembelian Pada Pt Harjagunatama Lestari (Toserba Borma) Cabang Dakota. Jurnal Ilmiah Manajemen, Ekonomi, \& Akuntansi (MEA), 2(2), 57-65. https://doi.org/10.31955/jimea. vol2.iss2.pp57-65.

Pratiwi-, D. (2020). PENGARUH BRAND IMAGE DAN BRAND TRUST TERHADAP KEPUTUSAN PEMBELIAN BEDAK MARCKS ( Studi Pada Mahasiswa Prodi D4 Manajemen Pemasaran Jurusan Administrasi Niaga Politeknik Negeri Malang ).

RACHMAN, D. A. (2017). Diponegoro Journal of Social and Political Science. Universitas Diponegoro, 1(1), 1-8.

Ramadani, M. (2019). Pengaruh kualitas pelayanan, promosi dan lokasi terhadap keputusan pembelian di toko handphone. IQTISHADequity, 1(2), 36-46.

Ruhamak, M. D., \& Rahmadi, A. N. (2019). Pengaruh E-WOM, Brand Image dan Brand Trust Terhadap Keputusan Konsumen (Studi Kasus Pada Lembaga Kursus Fajar English Course Pare-Kediri). BISNIS : Jurnal Bisnis Dan Manajemen Islam, 7(2), 233. https://doi. org/10.21043/bisnis.v7i2.6160

Sari, M. P., \& Sanjaya, V. F. (2020). Pengaruh Harga, Promosi, dan Kepercayaan Terhadap Keputusan Pembelian Produk YOU. Jurnal Manajemen Dan Bisnis (JMB), 2(1), 1-8. http:/jurnal. umitra.ac.id/index.php/JMB/article/view/510 
Soenawan, A. D., \& Malonda, E. S. (2015). Pengaruh Kualitas Produk, Kualitas Pelayanan dan Harga Terhadap Keputusan Pembelian Konsumen D ' Stupid Baker Spazio Graha Family Surabaya. Program Manajemen Perhotelan, Fakultas Ekonomi, Universitas Kris- ten Petra Email:, 395-409.

Sugiyono. (2016). Metode Penelitian Kuantitatif, Kualitatif dan R\&D. Alfabeth: Yogyakarta.

Tjiptono, F. (2016). Pemasaran Jasa. Andi: Yogyakarta. 